\title{
Livelihood implications of biofuel crop production: Implications for governance
}

\author{
Hunsberger, Carol ; Bolwig, Simon; Corbera, Esteve ; Creutzig, Felix
}

Published in:

Geoforum

Link to article, DOI:

10.1016/j.geoforum.2013.09.022

Publication date:

2014

Document Version

Publisher's PDF, also known as Version of record

Link back to DTU Orbit

Citation (APA):

Hunsberger, C., Bolwig, S., Corbera, E., \& Creutzig, F. (2014). Livelihood implications of biofuel crop production: Implications for governance. Geoforum, 54, 248-260. https://doi.org/10.1016/j.geoforum.2013.09.022

\section{General rights}

Copyright and moral rights for the publications made accessible in the public portal are retained by the authors and/or other copyright owners and it is a condition of accessing publications that users recognise and abide by the legal requirements associated with these rights.

- Users may download and print one copy of any publication from the public portal for the purpose of private study or research.

- You may not further distribute the material or use it for any profit-making activity or commercial gain

- You may freely distribute the URL identifying the publication in the public portal

If you believe that this document breaches copyright please contact us providing details, and we will remove access to the work immediately and investigate your claim 


\title{
Livelihood impacts of biofuel crop production: Implications for governance
}

\author{
Carol Hunsberger ${ }^{\mathrm{a}, *}$, Simon Bolwig ${ }^{\mathrm{b}}$, Esteve Corbera ${ }^{\mathrm{c}}$, Felix Creutzig ${ }^{\mathrm{d}, \mathrm{e}, \mathrm{f}}$ \\ a International Institute of Social Studies, Kortenaerkade 12, 2518 AX The Hague, Netherlands \\ b Department of Management Engineering, Technical University of Denmark, 4000 Roskilde, Denmark

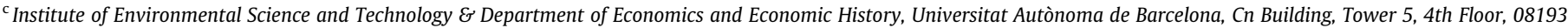 \\ Bellaterra, Spain \\ ${ }^{\mathrm{d}}$ Mercator Research Institute on Global Commons and Climate Change, Torgauer Straße 12-15, 10829 Berlin, Germany \\ e Technische Universtita t Berlin, Straße des 17 Juni 135, D-10623 Berlin, Germany \\ ${ }^{\mathrm{f}}$ Princeton Institute for International and Regional Studies, Princeton, NJ 08544, USA
}

\section{A R T I C L E I N F O}

\section{Article history:}

Available online $\mathrm{xxxx}$

\section{Keywords:}

Biofuel

Livelihood

Governance

Certification

Sustainability

Multi-criteria policy

\begin{abstract}
A B S T R A C T
While much attention has focused on the climate change mitigation potential of biofuels, research from the social sciences increasingly highlights the social and livelihood impacts of their expanded production. Policy and governance measures aimed at improving the social effects of biofuels have proliferated but questions remain about their effectiveness across the value chain. This paper performs three tasks building on emerging insights from social science research on the deployment of biofuel crops. First, we identify livelihood dimensions that are particularly likely to be affected by their cultivation in the global South - income, food security, access to land-based resources, and social assets - revealing that distributional effects are crucial to evaluating the outcomes of biofuel production across these dimensions. Second, we ask how well selected biofuel governance mechanisms address livelihood and equity concerns. Third, we draw insights from literature on non-energy agricultural value chains to provide one set of ideas for improving livelihood outcomes. Our analysis demonstrates that biofuel policies treat livelihoods as a second-degree problem, specifying livelihoods as an afterthought to other goals. We suggest integrating livelihoods into a multi-criteria policy framework from the start - one that prioritizes equity issues as well as overall outcomes. We also show that the instruments with strongest provisions for safeguarding livelihoods and equity appear least likely to be implemented. Together, shifting both the priorities and the relative hierarchy of biofuel governance instruments could help produce strategies that more effectively address livelihood and equity concerns.
\end{abstract}

(c) 2013 Elsevier Ltd. All rights reserved.

\section{Introduction}

Three main interests have motivated the recent wave of policies encouraging biofuel production and use. Concern over greenhouse gas (GHG) emissions raised interest in biofuels as a climate change mitigation strategy; fluctuating oil prices and uncertainty over future supplies drove interest in biofuels as an energy security strategy; and a desire for economic growth in the agriculture sector supported investment in biofuels as a rural development strategy (Franco et al., 2010; Howarth et al., 2009). The belief that biofuels could promote all three of these goals was partly based on analyses of the economic and climate change mitigation potential of biofuel production - analyses that paid little attention to other social and environmental considerations. For example, the Special Report on Renewable Energy Sources (SRREN) (IPCC, 2011), one of the most

\footnotetext{
* Corresponding author.

E-mail address: hunsberger@iss.nl (C. Hunsberger).
}

important attempts to assess the potential role of biofuels in the future global energy mix, focuses primarily on greenhouse gas reduction potential (in line with the report's mandate) and mentions other sustainability considerations only briefly. Social and livelihood outcomes have been conspicuously absent from global bioenergy assessment reports despite their importance to the overall question of whether and in what circumstances biofuels can be considered sustainable (Creutzig et al., 2012b).

'Sustainable biofuels' is a concept that warrants unpacking. Biofuels have been the subject of much ideological contestation (Fast, 2009). The ability to control biofuel discourses - including what counts as 'sustainable' biofuel - is a key form of power that can influence decisions with on-the-ground consequences for farmers and ecologies (Hunsberger, 2013; Kuchler and Linnér, 2012). In the economic literature and reports such as SRREN, 'sustainable' biofuels are typically considered to have low life-cycle GHG emissions and sometimes to provide other benefits, such as an income for rural communities. By contrast, the Roundtable on Sustainable 
Biomaterials (RSB, formerly Roundtable on Sustainable Biofuels) identifies 12 principles underlying the sustainability of biofuels, including land rights and local food security (RSB, 2010). Like the RSB, we believe that a wider range of (interrelated) social and ecological factors than GHG and income is necessary for biofuel production to be considered sustainable. In this paper we examine a range of possible livelihood impacts and their uptake in international biofuels regulation.

Recent research has critically examined social and environmental problems related to biofuels development. Social science research draws attention to the local social outcomes of biofuel production, particularly in the global South (e.g. German et al., 2012; Hodbod and Tomei, 2013; McMichael and Scoones, 2010). Research on indirect land use change has simultaneously challenged the view that biofuels necessarily produce climate mitigation benefits (Fargione et al., 2008; Hertel et al., 2010; Searchinger et al., 2008), results that were until recently insufficiently integrated into global assessment models (Creutzig et al., 2012a). Other environmental dimensions have also come under scrutiny, including effects on biodiversity (Fargione et al., 2010) and water resources (Larsen et al., this issue; Woodhouse, 2012).

Alongside these shifts, policy amendments and new governance initiatives have emphasized the social and environmental dimensions of biofuels. Several countries that had already implemented biofuel use targets modified their policies by adding sustainability requirements, including the US, the EU and the UK (Creutzig et al., 2011; EU, 2009; Renewable Fuels Agency, 2010). Some producer countries introduced new conditions on where biofuel production could take place, for example Indonesia (USDA Foreign Agricultural Service, 2011), or took steps to slow biofuel investments and allow more time to assess their implications, as in Tanzania (Browne, 2009). Meanwhile, new certification systems, multi-stakeholder 'roundtables' and voluntary guidelines have encouraged governments and the private sector to pursue environmental and social benefits across the value chain (Bailis and Baka, 2011; Lee et al., 2011). But how effective are these measures? Recent appraisals suggest that biofuel certification schemes have significant shortcomings, including weak attention to social criteria (German and Schoneveld, 2012), high barriers to participation (Lee et al., 2011 ), and a lack of guidance on governance practices with the result that 'business-friendly' schemes tend to dominate (Ponte, this issue).

Improving the governance of biofuels faces political challenges. Environmental and social policies remain under-enforced in many countries, while states and investors lack incentive to implement voluntary measures that contradict their own interests. Biofuel developments have increased already intense competition for arable land and in many cases have been associated with 'land grabs' (Borras and Franco, 2012; Borras et al., 2011) or 'green grabs' (Fairhead et al., 2012) that alter patterns of land use and property relations. Two ongoing trends complicate matters further: the basis of land governance appears to be shifting away from approaches based on territory toward ones based on flows of goods and resources; and non-state actors are assuming a more prominent role in land governance (Sikor et al., 2013). The goal of protecting and enhancing rural livelihoods in the context of biofuel production thus depends on the difficult task of designing and implementing governance mechanisms that are robust and resilient, while simultaneously confronting deeply entrenched power relations.

This paper asks how fully and in what ways biofuel governance initiatives seek to protect and enhance livelihoods at sites of production and along the value chain, particularly in developing countries, and how they could be strengthened in this regard. We systematically analyze a set of governance mechanisms chosen to reflect a variety of types of initiatives as well as an evolution of strategies over time. While we see social and environmental dimensions of sustainability as closely intertwined, in this paper we focus on livelihood and equity considerations because we believe they have been insufficiently taken up in global assessments of biofuels to date (Creutzig et al., 2013), and are likely also underrepresented in policies and strategies that have been informed by such assessments. In Section 2 we explain our interpretation of livelihoods and equity, review recent research on the local impacts of biofuel production, and identify key dimensions of livelihoods that are likely to be affected by the expansion of biofuel crops. In Section 3 we examine selected governance instruments, assessing how they address livelihood outcomes and equity. We also make a preliminary assessment of how widely each instrument has been implemented. In Section 4 we identify patterns and trade-offs arising from the analysis and discuss how similar problems have been approached in non-biofuel agricultural value chains. Section 5 offers possible strategies for strengthening biofuel governance efforts and identifies avenues for future research.

\section{Biofuels, livelihoods and equity}

The growth and consolidation of land areas in the global South dedicated to cultivating biofuel crops, including soy, oil palm, jatropha and sugar cane, is changing rural livelihoods in ways that we are still far from systematically understanding. Livelihoods comprise the capabilities, assets, and activities required for a means of living (Scoones, 1998, 2009). The term conveys not only economic factors of survival, such as income, but also non-economic ones such as social relationships, capabilities and institutions that mediate peoples' access to different income flows and other assets (Ellis, 2000). Both natural and socio-economic assets are critical for livelihoods and provide meaning to communities (Bebbington, 1999). Access to land and other natural assets is mediated by tenure regimes, which encompass property rights as well as formal and informal social relations and systems of authority that influence who gets access to and exercises control over land resources (Ribot and Peluso, 2003). Diversity in income streams and assets is a central characteristic of livelihoods in developing countries (Ellis, 2000). A livelihood is considered sustainable when it can cope with and recover from stresses and shocks (i.e. is resilient), and maintain or enhance its capabilities and assets without undermining the natural resource base (Ellis, 2000; Scoones, 1998, 2009).

While case study evidence detailing the place-specific livelihood impacts of biofuel production remains thin (Hodbod and Tomei, 2013), there are parallels between the current expansion of biofuel crops and trends in the production of other cash crops. Analyses of "boom crops" demonstrate that developments driven by strong market demand produce conflicts, winners and losers, particularly at local scale (see for example Gerber, 2011). Reviews of rubber, cocoa, oil palm, coffee and commercial tree plantations, as well as shrimp aquaculture, highlight that a lack of formal property rights has often facilitated their encroachment into customary tenure areas and the subsequent consolidation of formal property rights by migrants or powerful actors (Hall, 2003, 2011; Li, 2002). Reviews of industrial roundwood and rubber plantations suggest that such plantations have facilitated local processes of land ownership concentration, loss of customary rights of resource access, rural displacement, and socioeconomic decline in neighboring communities, with uneven benefits in the form of wage labor (Charnley, 2005; Kenney-Lazar, 2012).

Emerging research on biofuel crop expansion in the global South echoes some of these "boom crop" effects. Regarding income, mounting evidence suggests that the expansion of biofuel crops generates unskilled jobs and increases local farm and/or wage income, though the magnitude and extent of these gains 
depend on the production model, type of crop and configuration of the value chain (see e.g. Feintrenie et al., 2010). Small-scale, stateassisted oil palm plantations in Malaysia have reportedly increased farm income substantially (Cramb and Sujang, 2013), with similar results documented in Indonesia (Rist et al., 2010). In contrast, sugar cane and soy production in Brazil has mostly taken the form of large-scale, mechanized plantations that have benefited better-off farmers in richer regions while providing fewer opportunities to poorer farmers in regions where agriculture has historically been less profitable (Hall et al., 2009). Job opportunities can be limited by age and financial considerations. Mingorría and Gamboa (2010), for example, report that oil palm plantations in Guatemala only employ laborers between 14 and 30 years old and not older household heads, leading to income inequality and social conflicts. Where farmers plant slow-growing crops (e.g. jatropha, oil palm), the need for alternative income streams until the plants mature favors farmers with other income sources or adequate savings (McCarthy, 2010; Schoneveld et al., 2011; Skutsch et al., 2011) Even so, in some contexts, participation has led to indebtedness and reduced household food security (Ariza-Montobbio et al., 2010).

Biofuel crops interact with food security through their effects on households' physical or economic access to food, considering the nutritional, safety and preferential aspects of food consumption, as well as stability of access over time (Pinstrup-Andersen, 2009). Expanded biofuel production can reduce national and local food security via rising food prices or changes in land tenure regimes and patterns of food production. However, systematic evidence on both processes remains scarce. Increased ethanol production in the USA has been linked to increased maize prices in Latin America (Mitchell, 2008), though household panel data demonstrating how biofuel crop cultivation reduces access to local or self-produced food are still needed. Analysis of Guatemalan smallholders has shown that diverting scarce factors of production into palm plantations and away from food crops, in particular land, ${ }^{1}$ and the timing of a feedstock's peak labor requirements can decrease food production in situations of labor scarcity (Mingorría and Gamboa, 2010).

Studies of biofuel crop expansion and land tenure suggest that the production model and crop choice influence who benefits, as well as the extent to which tenure regimes governing access to and control over resources are disputed and transformed. The expansion of large-scale biofuel developments has displaced 'landless', informal or poor tenure holders through aggressive investments, land concentration, or land grabs, for example in India (Baka, 2013) and Brazil (Sauer and Leite, 2012). In a government-led, smallholder-focused jatropha cultivation program in Mexico (Skutsch et al., 2011), households without formal land titles were reportedly excluded from the program and its associated subsidies. A case study of jatropha production in Ghana (Schoneveld et al., 2011) found that women lost informal access to land and resources more easily than men. Outgrower oil palm schemes can also restrict tenure and resource rights, with households that previously relied on forest resources for income and food shifting to other livelihood activities (Julia and White, 2012; Obidzinski et al., 2012). Villagers near an oil palm processing facility in Central Kalimantan, Indonesia, reported water quality problems that affected their ability to fish (Larsen et al., this issue). These cases of loss of control over land and resources demonstrate the inseparability of social and environmental considerations.

\footnotetext{
1 This includes the degree of complementarity between biofuel and food crop cycles, and the extent to which 'surplus' resources exist in the household that can be mobilized to increase farm output.
}

Finally, emerging evidence shows that biofuel crops can influence health conditions. It has been argued that exposure to herbicides and other agricultural chemicals needs to be better monitored in plantations and outgrower schemes (Mink et al., 2012; Williams et al., 2012), and that necessary precautions are often unknown to workers (Gupta, 2012). Under some ecological conditions, plantations can be conducive to specific vector-borne diseases due to workers' high occupational exposure to transmitting insects (Bhumiratana et al., 2013). Tanga et al. (2011) note that oil palm plantations can facilitate transmission of malaria or dengue in parts of Africa by allowing their vectors to find more suitable breeding and survival conditions.

In light of this evidence, we argue that four interrelated aspects of livelihoods stand out as critical to understanding how biofuel crop deployment can reconfigure livelihoods: farm and wage income; food security; access to land and resources; and other assets including social (and gender) relations and health (Creutzig et al., 2013). The direction, magnitude and forms of impacts on these dimensions are likely conditioned by place-specific arrangements related to the production model, land tenure and value chains (Cramb and Curry, 2012), and by regional to global dynamics related to biofuel, food and fuel markets (Arndt et al., 2011). Different combinations of these factors can produce very different clusters of outcomes. A framework showing these interactions, developed by the authors in another paper (Creutzig et al., 2013), is summarized in Fig. 1.

We further argue that normative assessments of outcomes can dramatically differ depending on whether or not an equity lens (or distributional perspective) is adopted. In this article, we examine how the costs and benefits of biofuel crops are distributed across social actors (i.e. distributive justice). Our analysis mostly focuses on intra-generational concerns and adopts a prioritarian view of distributive justice (Parfit, 1997; Temkin, 2003), meaning that biofuel crops should not make worse off those who are comparatively poorer than others in the value chain and beyond. It is thus necessary to analyze who benefits from biofuel crop cultivation and how, as well as who does not benefit (or benefits less) and why, to improve our understanding of the implications of such deployment and support more informed decisions.

In the following sections we analyze how governance arrangements for biofuels engage with the livelihood dimensions identified above, and whether they focus only on overall (aggregate) outcomes or also employ an equity (distributional) perspective. For a selection of governance instruments ranging from policies to voluntary guidelines, we ask: how do their priorities relate to income, food, access to land and other assets? To what extent do the mechanisms address distributional (equity) effects? And, how much impact are these measures likely to have, taking into account their uptake by relevant actors? The answers to these questions will inform our analysis of how biofuel governance might be strengthened from the perspective of livelihoods and equity.

\section{Analysis of governance instruments}

Here we analyze how selected biofuel governance instruments address livelihoods and equity. Several types of mechanisms are relevant to expanded biofuel production, including formal rules such as binding government policies and voluntary measures such as certification systems. For reasons given below, we have selected a subset of instruments: (1) Fuel blending mandates related to the quantity of biofuel production or use - and subsequent policies with attention to sustainability - with a focus on the EU and Brazil; and (2) Voluntary measures related to sustainability criteria, with a focus on the RSB, International Sustainability and Carbon Certification (ISCC), and FAO Voluntary Guidelines on Responsible Governance of Tenure. 


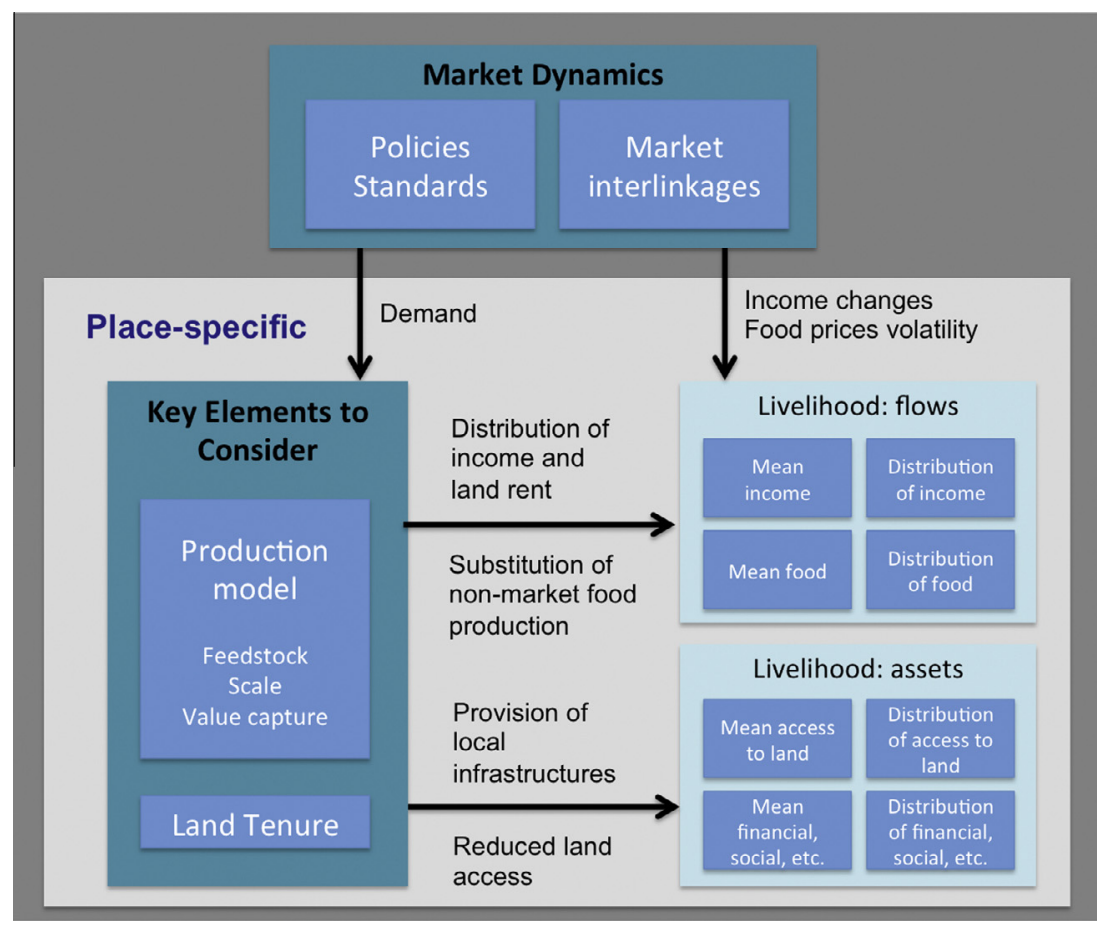

Fig. 1. Key livelihood aspects and mediating factors related to expanded biofuel production.

These instruments were chosen because they collectively represent most parts of the spectrum of biofuel production governance. Some of these measures are legally inscribed while others are voluntary instruments that nevertheless may constitute 'private' forms of market regulation or 'soft law.' In the first category, Brazil and the EU were chosen because they represent major exporters (Brazil) and importers (EU) of biofuels, and policies in both places have changed over time to include social or 'sustainability' criteria. We wanted to investigate this shift. In the second category, RSB and ISCC were chosen as two prominent certification schemes that have positioned themselves using different strategies. RSB projects itself as a consensus-based, multi-stakeholder initiative, while ISCC uses language of efficiency to appeal to businesses (Ponte, this volume). We wondered whether or not these different approaches correspond with different levels of engagement with livelihood issues. The FAO Voluntary Guidelines provide an opportunity to consider the role that policies on broader topics (in this case, land tenure) can play in governing biofuels. This is particularly important because biofuel policies are usually introduced where institutions already exist to govern land and water rights, environmental protection and labor conditions.

Collectively these measures loosely reflect a chronological shift from a focus on how much biofuel should be produced or used, to a wider set of concerns about how biofuels are produced. We acknowledge that measures of different types are not directly comparable - for example, policy frameworks can be expected to have different characteristics than certification schemes (for a thorough and direct comparison of certification schemes, see German and Schoneveld, 2012). Including several types of measures in the same analysis opens the question of whether weaknesses in one type of instrument might be addressed through complementary strengths in another type.

We begin with a text analysis of the selected mechanisms, exploring how strongly each emphasizes protecting and enhancing livelihoods whilst ensuring that costs and benefits are fairly shared across social groups and individuals. We do not examine the extent to which these instruments have been contested, endorsed and supported by multiple affected parties in their design, but focus instead on the principles for distributing benefits and costs during implementation and the resulting outcomes. Table 1 summarizes the instruments' key features.

\subsection{Fuel blending mandates}

\subsubsection{EU Directives}

Directive 2003/30/EC established biofuel blending targets using a rationale of climate change mitigation, energy security and rural development (EU, 2003). Later replaced by Directive 2009/28/EC, the 2003 Directive refers to biofuels for transport as "part of the package of measures needed to comply with the Kyoto Protocol" and asserts, "promoting the use of biofuels... could create new opportunities for sustainable rural development in a more market-oriented common agriculture policy." Directive 2003/30/EC does not mention social aspects of biofuel production aside from agricultural opportunities in an aggregate sense. The mandate was contextualized with the Fuel Quality Directive, which specified a required level of life-cycle emissions reduction and thereby restricted the choice of acceptable biofuels.

The 2003 Directive committed the European Commission to report every two years on: cost-effectiveness; economic and environmental outcomes; land use, cultivation intensity, crop rotation and pesticide use; and GHG mitigation. Implicitly, the 2003 Directive assumed that the biofuels needed to meet its targets would be produced within the European Union and would therefore be subject to European agricultural regulations. In sum, the 2003 Directive does not directly comment on any livelihood or equity aspects of biofuel production.

Directive 2009/28/EC (EU, 2009) replaces Directive 2003/30/EC and specifies sustainability criteria for the production of biofuels used in Europe. The Directive's preamble describes the need "to assess the possible impacts of biofuel production on agricultural food products and to take action, if necessary, to address shortcomings" (Item 9). It also states that "further assessment should be made of the environmental and social consequences of the production and 
Table 1

Key features of selected biofuel governance initiatives.

\begin{tabular}{|c|c|c|c|c|c|c|c|}
\hline Instrument & Stated priorities & Criteria & Scale & Implementation & Livelihoods & Equity aspects & Status \\
\hline $\begin{array}{l}\text { EU Directive 2003/ } \\
\text { 30/EC (2003) }\end{array}$ & $\begin{array}{l}\text { Climate change; } \\
\text { energy security; } \\
\text { rural development }\end{array}$ & $\begin{array}{l}\text { \% fuel blending; GHG; } \\
\text { economic performance; land } \\
\text { use; pesticide use }\end{array}$ & $\begin{array}{l}\text { Regional } \\
\text { including } \\
\text { imports }\end{array}$ & $\begin{array}{l}\text { Mandatory blending } \\
\text { targets }\end{array}$ & $\begin{array}{l}\text { Not specifically } \\
\text { included }\end{array}$ & Aggregate only & $\begin{array}{l}\text { Replaced by } \\
2009 \text { Directive }\end{array}$ \\
\hline $\begin{array}{l}\text { Brazil's ProAlcool } \\
\quad(1975)\end{array}$ & $\begin{array}{l}\text { Import substitution; } \\
\text { economic } \\
\text { development }\end{array}$ & $\begin{array}{l}\text { Sugarcane ethanol } \\
\text { production; fuel blending; } \\
\text { tech innovation }\end{array}$ & National & $\begin{array}{l}\text { Mandatory blending } \\
\text { targets }\end{array}$ & $\begin{array}{l}\text { Not specifically } \\
\text { included }\end{array}$ & $\begin{array}{l}\text { In practice, favoured } \\
\text { large-scale producers }\end{array}$ & $\begin{array}{l}\text { Crops suited to } \\
\text { small scale } \\
\text { dropped }\end{array}$ \\
\hline $\begin{array}{l}\text { EU Directive 2009/ } \\
\text { 28/EC (2009) }\end{array}$ & $\begin{array}{l}\text { Climate change; } \\
\text { energy security; } \\
\text { rural development; } \\
\text { social and env. } \\
\text { sustainability }\end{array}$ & $\begin{array}{l}\text { GHG; food availability and } \\
\text { prices; "wider development } \\
\text { issues;" land-use rights; } \\
\text { status of ILO conventions }\end{array}$ & $\begin{array}{l}\text { Regional } \\
\text { including } \\
\text { imports }\end{array}$ & $\begin{array}{l}\text { Social criteria require } \\
\text { impact reporting but not } \\
\text { mitigation; relies on } \\
\text { external certification, } \\
\text { audits }\end{array}$ & $\begin{array}{l}\text { Food production } \\
\text { and access; } \\
\text { wage income; } \\
\text { land }\end{array}$ & $\begin{array}{l}\text { Mostly aggregate; } \\
\text { equity concerns } \\
\text { implied through ILO } \\
\text { and mention of land- } \\
\text { use rights }\end{array}$ & $\begin{array}{l}13 \text { certification } \\
\text { schemes } \\
\text { approved as of } \\
\text { Nov } 2012\end{array}$ \\
\hline $\begin{array}{l}\text { Brazil's PNPB } \\
\quad(2004)\end{array}$ & $\begin{array}{l}\text { Market creation; } \\
\text { social inclusion }\end{array}$ & $\begin{array}{l}\text { Social Fuel Seal: Include small } \\
\text { farmers from poorer regions; } \\
\text { contracts, technical assistance }\end{array}$ & National & $\begin{array}{l}\text { Mandatory blending } \\
\text { targets; Social Fuel Seal } \\
\text { required for a portion of } \\
\text { production }\end{array}$ & $\begin{array}{l}\text { Farm income; } \\
\text { other assets } \\
\text { (capacity } \\
\text { building) }\end{array}$ & $\begin{array}{l}\text { Regional equity: } \\
\text { support farmers in } \\
\text { poorer regions }\end{array}$ & $\begin{array}{l}\text { Amended in } \\
2009 \text { to require } \\
\text { lower \% from } \\
\text { small farmers }\end{array}$ \\
\hline $\begin{array}{l}\text { RSB Principles and } \\
\text { Criteria (2010) }\end{array}$ & $\begin{array}{l}\text { Sustainable biofuel } \\
\text { production }\end{array}$ & $\begin{array}{l}\text { Human and labor rights; rural } \\
\text { social development; local } \\
\text { food security; land rights; } \\
\text { conservation; GHG; water; } \\
\text { soil; air }\end{array}$ & Global & $\begin{array}{l}\text { Voluntary, but approved } \\
\text { to certify for EU } 2009 \\
\text { sustainability criteria }\end{array}$ & $\begin{array}{l}\text { Food; wage } \\
\text { income; land; } \\
\text { other assets } \\
\text { (labor } \\
\text { conditions) }\end{array}$ & $\begin{array}{l}\text { ILO on labor equity; } \\
\text { encourages "special } \\
\text { measures" to improve } \\
\text { status of the } \\
\text { vulnerable }\end{array}$ & $\begin{array}{l}6 \text { operators } \\
\text { certified as of } \\
\text { April } 2013\end{array}$ \\
\hline $\begin{array}{l}\text { ISCC Sustainability } \\
\text { Requirements } \\
\quad(2011)\end{array}$ & $\begin{array}{l}\text { Sustainable, "carbon } \\
\text { friendly" bioenergy } \\
\text { production }\end{array}$ & $\begin{array}{l}\text { GHG; biodiversity; water; } \\
\text { soil; air; working conditions; } \\
\text { education; land rights }\end{array}$ & Global & $\begin{array}{l}\text { Voluntary, but approved } \\
\text { to certify for EU } 2009 \\
\text { sustainability criteria }\end{array}$ & $\begin{array}{l}\text { Labor; land } \\
\text { rights; other } \\
\text { assets (conflict, } \\
\text { health, safety, } \\
\text { education) }\end{array}$ & $\begin{array}{l}\text { ILO on labor equity; } \\
\text { working conditions, } \\
\text { land rights; side- } \\
\text { effects including } \\
\text { conflict }\end{array}$ & $\begin{array}{l}\text { Over } 2,500 \\
\text { certificates } \\
\text { issued; some } \\
\text { expired }\end{array}$ \\
\hline $\begin{array}{l}\text { FAO Voluntary } \\
\text { Guidelines } \\
\text { (2012) }\end{array}$ & $\begin{array}{l}\text { Better governance of } \\
\text { tenure of land, } \\
\text { fisheries, forests }\end{array}$ & $\begin{array}{l}\text { Protection, promotion of } \\
\text { tenure rights; conflict } \\
\text { prevention; access to justice }\end{array}$ & Global & Voluntary & $\begin{array}{l}\text { Land rights as } \\
\text { basis for } \\
\text { livelihoods, } \\
\text { food; conflict } \\
\text { prevention }\end{array}$ & $\begin{array}{l}\text { "Equity and justice," } \\
\text { gender equality; } \\
\text { clauses on indigenous } \\
\text { peoples }\end{array}$ & $\begin{array}{l}\text { Country } \\
\text { implementation } \\
\text { plans being } \\
\text { developed }\end{array}$ \\
\hline
\end{tabular}

a FAO Voluntary Guidelines on the Responsible Governance of Tenure of Land, Fisheries and Forests in the Context of National Food Security.

consumption of biofuels" (Item 9) and recommends that energy prices reflect "environmental, social and healthcare costs" where appropriate (Item 26). Unlike its predecessor, Directive 2009/28/ EC acknowledges that meeting blending targets will involve importing biofuels and raises concerns that biofuel production "in certain third countries might not respect minimum environmental or social requirements." It encourages the establishment of agreements and voluntary schemes to cover these areas (Item 74). The preamble also mentions land use changes including "displacement, the introduction of invasive alien species and other effects on biodiversity, and effects on food production and local prosperity" (78). The 2009 Directive thus builds social considerations, both inside and outside Europe, into its justification much more strongly than the 2003 Directive.

Article 17 outlines the Directive's sustainability criteria. Environmentally, it specifies mandatory GHG reductions and discourages biofuel production on high-carbon and high-biodiversity land. The social criteria require the Commission to report every two years on "the impact on social sustainability in the Community and in third countries of increased demand for biofuel, on the impact of Community biofuel policy on the availability of foodstuffs at affordable prices, in particular for people living in developing countries, and wider development issues" including land-use rights (Article 17:7). Further, the Commission is asked to report whether or not countries that produce biofuels have ratified and implemented a list of Conventions of the International Labor Organisation (ILO) concerning forced labor, child labor, discrimination, the right to organize, and equal pay for women and men (Article 17:7).

Directive 2009/28/EC goes much further than 2003/30/EC in acknowledging the potential for biofuels to impact livelihood considerations: food production and access; wage income and labor conditions; and land-use rights. Attention to distributional outcomes is implied through the gender, age and anti-discrimination provisions of the ILO Conventions, even though requiring the
Commission to report whether these Conventions have been adopted in producer countries is not the same as requiring that the Conventions be adopted and implemented. Some believe that the decision to make social criteria subject only to reporting was influenced by fears that if compliance were made mandatory, it would trigger disputes through the World Trade Organization (Ackrill and Kay, 2011; Di Lucia, 2010). The 2009 Directive depends on additional agreements such as the ILO conventions, as well as on private certification systems, to ensure its sustainability criteria are met.

\subsubsection{Brazil's ProAlcool and Biodiesel programs}

Brazil's National Alcohol Program (ProAlcool) was designed to increase the quantity of biofuel production and use. Brazil instituted a $5 \%$ ethanol blending requirement in 1931, but the oil price shocks of the early 1970s motivated the government to raise its fuel blending targets and establish ambitious production targets for ethanol from sugar cane through the ProAlcool program in 1975 (Goldemberg, 2009). These mandates were supported with financial incentives to producers and investments in technological research, for example to develop engines that could run on ethanol. One of ProAlcool's stated objectives was to reduce ruralurban migration by providing rural employment opportunities, but the combination of sugar cane's short harvesting season and the tendency toward mechanization in the industry failed to provide long-term jobs (Hall et al., 2009). The program's financial incentives served to benefit large-scale producers and processers in richer parts of the country where sugar cane was already established, while more labor intensive crops such as cassava and sweet potato, which were initially included in the program and could have benefited small-scale producers in northeastern Brazil, were abandoned when they proved uncompetitive (Hall et al., 2009). Recognizing these shortcomings, Brazilian policymakers adopted a different approach to biodiesel. 
Brazil's National Program of Production and Use of Biodiesel ( $P N P B)$ gives stronger attention to social and livelihood concerns than ProAlcool. Introduced in 2004, PNPB includes biodiesel blending targets meant to boost demand, financial support for research and development, and the Social Fuel Seal - a set of measures designed to benefit small-scale producers from poorer areas (Hall et al., 2009). In order to earn the Social Fuel Seal and qualify for financial incentives as well as contracts guaranteeing that the government will purchase their product, biodiesel companies must buy part of their feedstock from small-scale producers from the north or north-east of the country, sign contracts with those farmers and give them technical assistance. Castor and palm oil, which can be produced by smallholders, are encouraged under the program. Brazil's biodiesel policy thus attempts to improve opportunities for capacity building and farm income through incentives that seek to shape both the production model and functioning of biodiesel markets. It considers equity at the regional and community levels by encouraging the participation of smallholders and trying to attract processing capacity to parts of the country with lower levels of economic development.

In terms of uptake, despite the program's goal of promoting small-scale cultivation of castor and palm oil, large-scale soy producers appear to have taken over an increasing share of the biodiesel industry (Hall et al., 2009). The number of family farmers enrolled in the program has remained well below the government's target of 200,000; as of 2010, approximately 100,000 families were identified as participating in PNPB, but only 246 of these were located in the north of the country - one of the program's target regions (César and Batalha, 2013; Wilkinson and Herrera, 2010). Cooperatives, given a stronger role in the program following a policy amendment in 2009 , have reportedly leveraged the resources available through PNPB to improve social inclusion for many family farmers, even though these farmers often have not ended up participating in biodiesel value chains (Stattman and Mol, this issue).

\subsection{Voluntary measures}

\subsubsection{Roundtable on Sustainable Biomaterials}

As a non-state governance initiative, the RSB Principles and Criteria (RSB, 2010) outline certification requirements for 'sustainable' biofuels covering human and labor rights, rural and social development, local food security, land rights, GHG emissions, conservation, soil, air, and water. Feedstock-specific certification can also be obtained through the Roundtable on Sustainable Palm Oil (RSPO) and Roundtable on Responsible Soy (RTRS). The RSB guidelines apply to four stages in the value chain: feedstock production, feedstock processing, biofuel production and biofuel blending. RSB is an approved certification scheme under the EU 2009 Directive; therefore, many of their criteria overlap - though RSB arguably goes well beyond the minimum EU requirements.

RSB Principle 4 aligns with ILO positions on forced labor, child labor, discrimination, minimum wage, limits to overtime and the right to organize. Principle 5 on rural and social development applies to a wider circle of people in areas where biofuel activities take place. Criterion 5.a takes an aggregate view of wellbeing: "In regions of poverty, the socioeconomic status of local stakeholders impacted by biofuel operations shall be improved." To achieve this, Criterion 5.a encourages creating long term jobs for local residents, retraining workers in the case of mechanization, expanding local access to modern energy, forming co-operatives, creating opportunities for local ownership or shareholding in biofuel operations, and establishing or maintaining schools, medical facilities or homes. Criterion 5.b calls for "special measures that benefit and encourage the participation of women, youth, indigenous people and the vulnerable in biofuel operations."

Principle 6 asks biofuel operators to protect and enhance local food security, starting by assessing the potential impacts of biofuel operations on food production as well as on "cross-cutting requirements for food security including land, water, labor, and infrastructure." Recommended measures include "setting aside land for food growing, increasing yields, providing opportunities for workers to carry out household-level food production, sponsoring agricultural support programs and activities, and/or making value-added food byproducts available to the local market." These actions focus on increasing food supplies rather than other determinants of access to food. Principle 9 requires operators to "maintain or enhance" freshwater quantity and quality and avoid interfering with water supplies that local communities need "for subsistence," but also to "respect prior formal or customary water rights" including those of indigenous communities. Principle 12 on land rights mandates that operations may only begin after existing formal and informal land use rights have been documented, and free, prior and informed consent with land users has been obtained.

The RSB guidelines thus cover all four livelihood dimensions. RSPO and RTRS engage with particular characteristics of oil palm and soy. The RSB statements on equity, particularly on measures to benefit the vulnerable and ensure respect for customary land and water rights, go beyond the language found in the instruments reviewed so far. However, the deeper engagement of RSB, RSPO and RTRS with livelihood and equity considerations is undermined by their limited implementation to date. The principles also take the perspective of minimizing harmful impacts from biofuel production rather than evaluating all options, such as prioritizing the maintenance and improvements of benefits from pre-existing land-tenure regimes.

In 2011 RSB had 120 members, including feedstock growers, industrial biofuel producers and inter-governmental organizations (RSB, 2011). These are divided into chambers, which elect a steering board. The board makes all decisions by consensus. Membership involves endorsing the RSB objectives and committing time and resources to advancing the RSB standard (RSB, 2013b); thus it is not the same as certification. Some members (e.g. NGOs) are not seeking certification, while certificate holders are not necessarily members of RSB. In April 2013 RSB had only 6 certified operators. The amount of land under certified production comprised 3393 ha of Jatropha curcas in Mexico, and 10,364 ha and 10,000 ha of sugarcane in Peru and Sierra Leone, respectively (RSB, 2013a). Thus despite a high number of members, relatively little certification has taken place so far.

RTRS has 150 members. Data for 2012 reveal 333,596 ha certified, yielding almost 1 million tons of certified soy produced by nine companies from Argentina, six from Brazil, one from Uruguay and three from India (RTRS, 2013). Total soy cultivation in these countries covered more than 52 million ha in 2011 and produced almost 136 million tonnes (FAO, 2013), meaning that certified soy remains below $1 \%$ of production in these countries. RSPO has the largest membership of the three with 1050 members in 2012, of which almost 10\% were growers (RSPO, 2012). Approximately 1.2 million cultivated hectares have been certified, producing almost 7 million tonnes of crude and kernel palm oil. These amounts represent $12 \%$ of global crude and kernel palm oil production (FAO, 2013).

\subsubsection{International Sustainability and Carbon Certification}

The ISCC standard is another voluntary certification system for biomass and bioenergy. It is supported by the German government and approved under the European Renewable Energy Directive (2009/28/EC). The standard's sustainability principles encompass 
six principles and 91 criteria (ISCC, 2011). The latter are divided into "major musts" and "minor musts;" all of the former and at least $60 \%$ of the latter must be fulfilled for a successful audit. Principle 1 notes that biomass should not be produced on land with high carbon content or high biodiversity value. Principle 2 focuses on best practices for protecting soil, water and air and good agricultural management.

Principle 3 aims to guarantee safe working conditions with emphasis on health, hygiene and safety. However, only three of 12 criteria under this principle are considered "major musts." Principle 4 states: "biomass production shall not violate human rights, labor rights or land rights. It shall promote responsible labor conditions and workers' health, safety and welfare and shall be based on responsible community relations." Further, it recommends that farm managers and employees' representatives develop a self-declaration that "contains commitment to the ILO core labor standards, respect for living wage, respect for the social environment, respect for legal land titles, sufficient compensation for communities, commitment to solve social conflicts, (and) fair contract farming arrangements." Yet again, only 7 out of 22 criteria are considered "major musts," including equality of opportunity, avoidance of forced or child labor, right to collective organization, and guaranteed schooling for children living on the farm. "Minor musts" include participatory social assessment, conflict mediation and/or compensation for workers and surrounding communities, and food security. Principle 5 demands compliance with relevant national and international legislation, emphasizing land tenure rights: "documents (must) show legal ownership or lease, history of land tenure and the actual legal use of the land. The producer must identify existing land rights and respect them." Both of these are considered "major musts."

ISCC has 66 members (ISCC, 2013a) and has issued over 2500 certificates to companies at various stages of the value chain (see Ponte, this issue for more detail). Of these, only 38 certificates have involved audits at farm level, of which 15 had expired and not been renewed as of April 2013. The 23 currently valid include 11 plantations of oil palm in Malaysia and Indonesia, one of J. curcas in Senegal, one of sugarcane in Costa Rica, one of cassava in Panama, and another nine certificates for wheat and corn in Eastern European countries (ISCC, 2013b). There is no public access to company reports on the number of certified hectares.

\subsubsection{Other relevant guidelines}

The Voluntary Guidelines on Responsible Governance of Tenure of Land, Fisheries and Forests in the Context of Food Security, developed by the United Nations Committee on Food Security under the auspices of the Food and Agriculture Organisation, has a scope that is highly relevant but not exclusive to biofuels. The guidelines portray governance of land tenure as a foundation for "food security and progressive realization of the right to adequate food, poverty eradication, sustainable livelihoods, social stability, housing security, rural development, environmental protection and sustainable social and economic development" (Objective 1.1). They identify governments as the main actors responsible for safeguarding tenure rights, preventing conflicts and providing access to justice, making more modest requests for businesses to exercise "due diligence" to avoid undue harm.

The guidelines discuss equity considerations in several forms. "Equity and justice" and "gender equality" are among the document's principles of implementation (General principle 3.1), while the guidelines repeatedly emphasize the importance of securing benefits for vulnerable and marginalized people. Thus, the guidelines foreground equity considerations. Land tenure is portrayed as the foundation for attaining a broad suite of social and livelihood goals. Like the RSB, the voluntary character of the guidelines is likely to complicate implementation. The guidelines were en- dorsed by the Committee on Food Security in March 2012 and it is now up to individual governments to make national implementation strategies, e.g. by reforming legislation related to land investments and agricultural development.

Table 1 summarized key characteristics of the reviewed governance instruments based on the text of the documents and the literature reviewed in Section 3. Fig. 2 visually presents how the livelihood dimensions of income, food, land and other assets are treated in the instruments, revealing important differences. "First-round" policies focused on stimulating biofuel markets (EU, 2003 and ProAlcool) include the fewest livelihood concerns. "Second-round" policies (EU, 2009 and Brazil's PNPB) are explicit about more livelihood aspects, but are hampered by limitations in how widely and forcefully they apply. The EU 2009 Directive is more focused on reporting social impacts than mitigating them, while Brazil's Social Fuel Seal initially targeted 50\% of production by smallholders, but in 2009 reduced the required share to $30 \%$. The certification schemes (RSB and ISCC) and voluntary guidelines (FAO) have the most comprehensive coverage on livelihoods and equity, but are voluntary in character. The next section explores these patterns in more detail.

\section{Discussion}

\subsection{Patterns and trade-offs in biofuel governance}

Livelihood considerations and distributional effects have become more prominent in biofuel governance initiatives over time. This trend corresponds with a broad shift both in the priorities of instruments (from narrower concerns with climate change mitigation and economic growth to a broader emphasis on 'sustainability') and in the types of instruments (from mandatory, government-led initiatives to voluntary, multi-stakeholder ones).

Some livelihood considerations are better represented than others. Food security, land rights and labor conditions receive more attention in the reviewed instruments than other assets including social cohesion and health. Distributional outcomes are particularly under-represented in the set of approaches reviewed here. Some of the instruments that discuss equity express it in terms of regional equity (e.g. Brazil's Social Fuel Seal, see Section 3.1.2) or gender equity (e.g. measures that build on ILO Conventions). Instruments that recommend taking special measures to address the needs of indigenous people (Voluntary Guidelines) or 'the vulnerable' (RSB) lack detail on how to approach this task. These instruments do not make clear how to identify who 'the vulnerable' are let alone how to accommodate their needs, or how to identify and manage impoverishment or conflicts other than through ill-defined 'compensation' (e.g. ISCC).

German (2012) identifies three key elements of governance substantive scope, reach, and implementation mechanisms ${ }^{2}$ and argues that a given instrument's effectiveness is limited by its performance in whichever of these areas it is weakest. Trade-offs between these areas appear to be occurring in the instruments we reviewed. Such trade-offs may enable agreement or increase buyin from multiple actors, but they also limit the strength of the instruments.

First, the instruments with the broadest scope and most substantive detail on livelihoods and equity tend to be voluntary. This is no coincidence. The FAO sought to achieve broad buy-in by convening multi-stakeholder consultations to inform the development of the Voluntary Guidelines. In doing so, the process involved find-

\footnotetext{
2 Substantive scope refers to the range of outcomes that a measure aims to influence; reach refers to the membership or proportion of activities covered by the measure; and implementation mechanisms refer to capacity for enforcement and
} verification (German, 2012). 


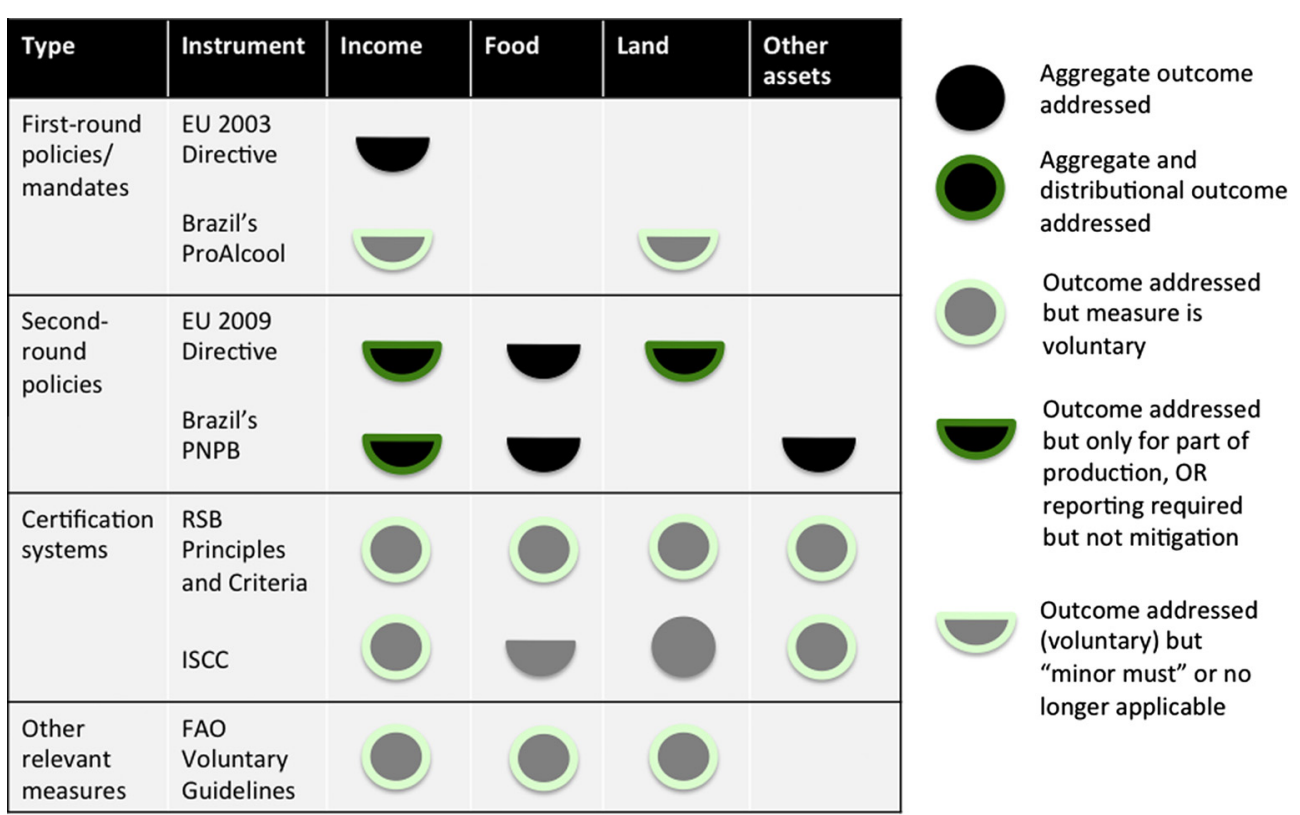

Fig. 2. Presence and relative strength of livelihood and equity provisions in the reviewed governance instruments.

ing a balance between articulating strong criteria for improving governance of land tenure on behalf of the most vulnerable - the achievement of which would in many cases require curtailing activities that follow conventional patterns of economic growth and seeking endorsement from the same governments that will be responsible for implementing these principles. This placed governments in the position of having considerable influence on the substantive scope of the guidelines as well as holding the key to their implementation. Keeping the guidelines voluntary allows states maximum flexibility to pursue the dual task of facilitating economic growth on one hand, while maintaining basic political legitimacy on the other (Fox, 1993).

In the case of certification standards, multi-stakeholder discussions were held to agree on the set of sustainability principles and criteria, albeit such agreement was generally made with a lack of consensus on what 'sustainability' meant, and a lack of inclusion of some relevant stakeholders from developed and developing countries (Partzsch, 2011; Schouten et al., 2012). While the EU 2009 Directive requires that its sustainability criteria be met, producers can choose between approved certification schemes. This means that while certification of some kind is mandatory, any particular scheme is voluntary. The relatively low number of hectares under certified production, particularly of RSB, RTRS and RSPO, has been explained by the fact that major importers of soy and palm oil are not yet showing a strong interest in paying premiums for certified production (Ponte, this issue; Laurance et al., 2010). The more widespread uptake of ISCC speaks, on one hand, to the early arrival of the standard in the European market and, on the other, to its less inclusive and transparent certification system which places fewer demands on certified companies (Ponte, this issue). The ISCC's flexible approach regarding which sustainability criteria to implement is likely appealing to producers. To the extent that producers are seeking certification for the EU market, this flexibility likely affects their choice of scheme. However, the relatively low number of active certificates overall suggests that producers may be targeting markets that do not require certification at present.

Second, the certification system can reinforce one production model over others even as it seeks to reduce the impacts of that production model. For example, of all the instruments reviewed, the RSB addresses the broadest set of social criteria. But it has been critiqued for presenting barriers to entry (such as high costs) that privilege large-scale producers, despite pilot efforts to certify small-scale producers (Lee et al., 2011). Although such certification schemes can encourage large-scale producers to take measures to mitigate threats to livelihoods and equity, for now they appear less able to encourage alternative production models that might avoid some of these effects to start with.

Third, certification schemes can be compromised by global market dynamics. Voluntary incentives designed to operate at sub-national or national scales risk being threatened by market dynamics at regional or global scales. For example, Social Fuel Seal's incentives to encourage smallholder production in Brazil appear to be overpowered by counter-incentives favoring economies of scale that are built into biofuel markets beyond the national level (Hall et al., 2009). This raises the question: who has the ability, let alone the authority, to influence broad market dynamics and equilibrium effects? The RSB suggests that governments have the responsibility to do so, but the biofuel policies and meta-standards discussed here do not yet show evidence of governments actively engaging with this concern.

In theory, national laws on land tenure, resource rights, environmental protection and labor are in a stronger position to influence practice than voluntary measures specific to biofuels. Schut et al. (2013) contend that if such policies are effectively designed and implemented, additional instruments aimed at governing biofuel production become unnecessary. However, experiences in Brazil (Newberry, this issue) and Indonesia (Larsen et al., this issue) suggest that implementing such laws is often problematic. In Mozambique, a working group linked to the development of the National Biofuel Policy and Strategy analyzed relevant policies and processes across spatial, temporal, administrative, institutional and economic scales, and studied how cross-scale challenges had been tackled in other countries and sectors to inform the first African national framework on sustainable biofuels (Schut et al., 2013). Among other outcomes, this process gave the government of Mozambique the power to revoke land titles from investors who were not meeting legislative requirements after the first 


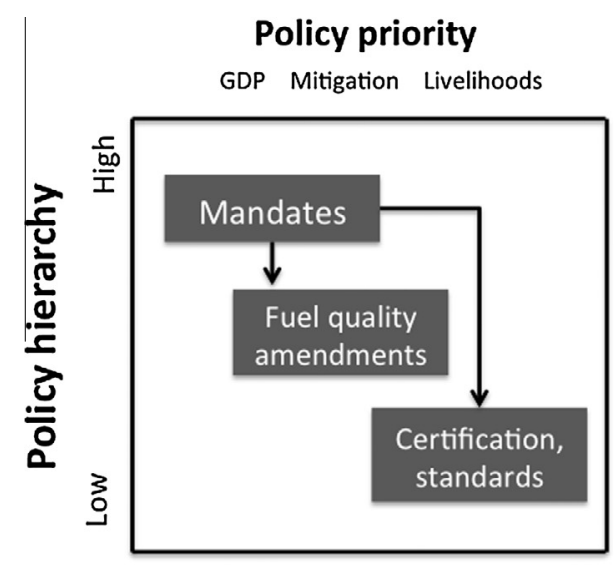

(a) Historical development
GDP Mitigation Livelihoods

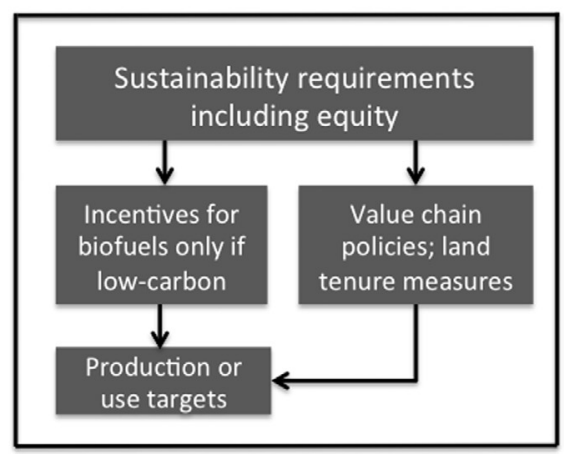

(b) Livelihood reconfiguration

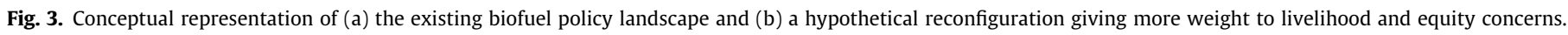

two years - power which the government exercised when it cancelled an unfulfilled sugarcane-ethanol contract in December 2009 (Schut et al., 2013).

\subsection{Reimagining biofuel governance}

Based on our analysis we have developed a simplified conceptual diagram of the biofuel policy landscape and a re-imagining of what it could look like if it were to foreground livelihood and distributional concerns (Fig. 3).

Panel (a) depicts the historical progression of biofuel governance instruments in terms of their thematic priorities and relative hierarchy. In this representation, the focus was initially on quantity-based biofuel blending mandates and production targets, designed in large part to address economic and climate change mitigation goals. These policies were supplemented first by fuel quality standards aimed at reducing GHG emissions (e.g. Renewable Fuel Standards and Fuel Quality Directives). Later, they were further amended or supplemented by sustainability standards and certification mechanisms (e.g. RSB and ISCC) that aim to improve livelihood outcomes, among other goals. These three stages represent a cascade of progressively lower items in the policy hierarchy, based on the order of their introduction as well as their enforceability - the instruments higher in the hierarchy are mandatory while the lower ones tend to be voluntary.

In panel (b) we propose a re-prioritization of governance instruments such that multi-criteria goals including livelihoods and equity would rise to the highest level in the policy hierarchy. Such multi-criteria goals can be interpreted as guardrails of a 'tolerable windows approach', identifying permissible pathways (PetschelHeld et al., 1999). This would mean that policy-makers in both producing and importing countries would need to adopt existing voluntary guidelines and make all or most of their provisions mandatory, for instance by extending the content of legal provisions as discussed in the Mozambique example above. A multi-criteria 'sustainability' goal could be supported on the livelihood side by measures that promote participation and value capture by smallholders in biofuel value chains (discussed further in Section 4.3), as well as measures to promote and protect equitable land tenure, access to ecosystem services and economic opportunities for the rural poor. On the environmental side, second-order policies could include incentives for biofuel production only if they met clear and specific criteria for reducing GHG emissions and safeguarding ecosystems. Quantity-based targets would drop to the lowest level of the hierarchy, meaning they could only be pursued if and when all of the above criteria were met. As one example of such a shift, sustainability criteria such as those in the EU 2009 Directive could be made dependent on the more comprehensive provisions on land tenure and rights spelled out by the RSB and FAO, and consequently forbid imports from countries where the expansion of biofuel crops involves de facto displacement of rural people without free, prior and informed consent and adequate compensation.

\subsection{Governance, upgrading and certification in agro-food value chains}

To think more specifically about how the reconfiguration of the biofuels policy landscape could be realized, we draw lessons from non-energy agricultural value chains in which standards play an important role. Value chain interventions represent one strategy among many for improving smallholder livelihoods. We consider the agro-food value chain and standards literature because it reveals how actors have grappled with four relevant problems: what kinds of interventions promote livelihood benefits for smallholders; how producer upgrading can be achieved in a way that benefits livelihoods; what value chain governance means for producer upgrading; and under what conditions smallholders benefit from certification. Table 2 summarizes relevant observations and their implications for biofuels.

\subsubsection{Value chain interventions}

Biofuel production in developing countries is frequently established with support from local governments and foreign donors. Humphrey and Navas-Alemán (2010) identify two prevailing modes of intervention in agro-food value chain projects. The first is 'lead firm' interventions that use strong actors, sometimes large multinational companies, as leverage points for upgrading smallholders' production, for example using contract farming through which smallholders are certified to private standards. ${ }^{3}$ The success of such schemes in including smallholders in remunerative value chains while raising livelihoods is debated (Barrett et al., 2012; Bolwig et al., 2009; Jones and Gibbon, 2011). Those studied by

\footnotetext{
3 See, e.g., Bolwig et al. (2009) and Jones and Gibbon (2011) for the EU organic
} standard, and Jaffee et al. (2011) for the GlobalGAP standard. 
Table 2

Conditions for smallholder benefits from agro-food certification and the relevance to biofuels.

\begin{tabular}{|c|c|c|}
\hline Type of condition & Explanation & Relevance and specific issues for biofuels \\
\hline Corporate resources & $\begin{array}{l}\text { The scheme operator has sufficient resources to cover (or share with } \\
\text { donors) the costs of establishment and scaling-up }\end{array}$ & $\begin{array}{l}\text { High relevance. So far operators have ranged from well-funded OECD- } \\
\text { based energy companies or subsidiaries to small local businesses }\end{array}$ \\
\hline $\begin{array}{l}\text { Corporate market } \\
\text { experience }\end{array}$ & $\begin{array}{l}\text { The operator has prior experience with conventional and certified } \\
\text { markets, since it is necessary to operate in both due to limited } \\
\text { demand for certified produce }\end{array}$ & $\begin{array}{l}\text { High to medium relevance. Biofuel markets differ in their technical and } \\
\text { sustainability requirements between countries and regions but there } \\
\text { is little differentiation within countries/regions. Some markets } \\
\text { experience oversupply making the ability to sell in several markets } \\
\text { advantageous }\end{array}$ \\
\hline $\begin{array}{l}\text { Corporate market } \\
\text { access }\end{array}$ & $\begin{array}{l}\text { The operator has either obtained advanced commitments from } \\
\text { importers or is itself an international trading company }\end{array}$ & $\begin{array}{l}\text { Medium relevance. Biofuel is storable but storage costs may be high. } \\
\text { Some biofuels are niche products, and quality and traceability issues } \\
\text { are significant, so finding buyers can be difficult and costly }\end{array}$ \\
\hline $\begin{array}{l}\text { Low certification } \\
\text { entry barriers for } \\
\text { farmers }\end{array}$ & $\begin{array}{l}\text { High farmer entry barriers entail greater investment costs and risks } \\
\text { both for operator and for farmers }\end{array}$ & $\begin{array}{l}\text { High to medium relevance. Investment costs vary by feedstock; } \\
\text { perennials generally higher than annuals. Complexity of life-cycle } \\
\text { GHG accounting may entail high costs. Stricter and multi-criteria } \\
\text { standards likely incur higher compliance costs for farmers and } \\
\text { operators }\end{array}$ \\
\hline $\begin{array}{l}\text { Price spread between } \\
\text { certified and } \\
\text { uncertified } \\
\text { produce }\end{array}$ & $\begin{array}{l}\text { The conventional produce market has a price spread between average } \\
\text { and premium quality, allowing operators to recover costs (and still } \\
\text { pay farmers premiums) when certified markets are saturated }\end{array}$ & $\begin{array}{l}\text { Medium to low relevance. Engine fuel standards are very similar across } \\
\text { markets, so quality-based price differentiation is likely to be small. } \\
\text { Other uses such as electricity generation may be more flexible in } \\
\text { terms of fuel quality }\end{array}$ \\
\hline $\begin{array}{l}\text { Appropriate donor } \\
\text { support }\end{array}$ & $\begin{array}{l}\text { Donor support for certification and scheme establishment is of } \\
\text { limited duration and directed primarily at the commercial viability of } \\
\text { the operation }\end{array}$ & $\begin{array}{l}\text { High relevance. Many biofuel projects in developing countries involve } \\
\text { government or donor support and are (likely to be) implemented in } \\
\text { ways similar to other agricultural sector projects }\end{array}$ \\
\hline $\begin{array}{l}\text { Absence of } \\
\text { fundamental } \\
\text { constraints }\end{array}$ & $\begin{array}{l}\text { Participation in international markets depends not just on } \\
\text { certification but also on fundamental matters of management, } \\
\text { applied research, technology transfer, logistics and infrastructure }\end{array}$ & $\begin{array}{l}\text { High relevance. As an immature industry, biofuel production faces a } \\
\text { range of fundamental constraints in addition to certification. The } \\
\text { specific physical characteristics of biofuels and economies of scale in } \\
\text { processing render existing infrastructures insufficient or unsuitable }\end{array}$ \\
\hline
\end{tabular}

Source: Adapted from Bolwig et al. (2013) when not indicated otherwise.

a Source: Diaz Rios et al. (2009).

Humphrey and Navas-Alemán (2010) did not necessarily target poor people and exhibited a weak explicit linkage to poverty reduction. Substantial technical, organizational and financial resources are needed to process, transport, certify, and trade in biofuels. Therefore, smallholder inclusion into biofuel value chains likely depends on establishing contract-farming arrangements between small feedstock producers and larger companies. Hence project support in this area will likely share many characteristics with agro-food 'lead firm' interventions, including uncertain and conditional livelihood benefits.

Agriculture in developing countries generally suffers from weak value chain linkages with serious consequences for farm gate prices, product quality, stability of supply, traceability and certification options, and access to inputs, all of which reduce smallholder benefits and overall chain performance. Hence, the second, and more common, mode of intervention that Humphrey and Navas-Alemán (2010) identify is 'chain linkage programs' designed to strengthen and diversify smallholder market linkages, provide them with new skills and information, and improve knowledge and resource flows along the chain. Chain linkage programs were found to be more targeted towards the poor than lead firm programs. ${ }^{4}$

For both modes of intervention Humphrey and Navas-Alemán (2010) observe a lack of rigorous impact assessments on how value chain interventions affect livelihoods. For standards-heavy value chains, recent research shows that measurable impacts on farm income can be achieved under certain conditions although cases of 'verified' smallholder benefits of certification are still few (Bolwig et al., 2013). Lessons for biofuel deployment can nevertheless be drawn from value chain research and interventions, particularly three strategic aspects: producer upgrading, governance, and certification to standards.

\footnotetext{
${ }^{4}$ Several programs included elements of both modes of intervention.
}

\subsubsection{Producer upgrading}

Many biofuel value chains are characterized by productivity and market coordination issues, and experience from the agro-food sector suggests that realizing smallholder benefits from value chain participation depends on addressing both issues simultaneously (Mitchell and Coles, 2011; Riisgaard et al., 2010). Riisgaard et al. (2010) use the concept of upgrading (Humphrey and Schmitz, 2002) to identify possibilities for producers to 'move up the value chain', either by shifting to more rewarding functional positions, or by making products that have more value-added or can provide better returns to producers. Riisgaard et al. (2010: 196) broaden the definition of upgrading to encompass "a desirable change in chain participation that increases rewards or reduces exposure to risk" - meaning that change should not only be evaluated in terms of income but also poverty, gender, labor and environmental outcomes. Achieving this shift requires improving the terms on which rural people participate in value chains, and understanding how those terms affect the balance between rewards, risks and costs, and not only avoiding exclusion from certain markets (Bolwig et al., 2010).

A strategic implication is that producers must carefully evaluate their participation in emerging biofuels value chains, in terms of how this participation is organized, how it affects livelihoods in a broad sense, and whether producing for other markets is preferable. Hence, issues of risk and vulnerability must be considered in addition to income. Supporting decision-making in this area involves enabling producers to access and interpret information about options and possible outcomes of participation in biofuels markets. This task seems suitable for farmer associations, extension services and NGOs. Farmers' ability to make informed decisions depends on their access to information, including whether they are reached by these organizations. Few biofuels standards currently have criteria to help ensure such 'informed participation' in biofuel value chains. The ISCC specifies the need to inform employees of "issues affecting the business or related to worker health, safety and welfare" (criteria 4.9), but only as a "minor 
must." Under Brazil's PNPB, since the policy was amended in 2009, cooperatives have been given new incentives to assist family farmers with biodiesel feedstock production as well as new privileges to link these farmers with buyers in order to obtain the Social Fuel Seal (Stattman and Mol, this issue). The amended PNPB may therefore create an opportunity for cooperatives to engage with smallscale farmers about options and outcomes.

\subsubsection{Governance and certification}

Value chain governance refers to the process of exercising control along the chain by specifying what product should be supplied, by whom, in what quantity, when, how it should be produced, and at what price (Bolwig et al., 2010; Gibbon et al., 2008). Power relations in agricultural (including biofuel) value chains are highly asymmetrical. Agricultural production can be carried out by many small producers, while processing, international trade and retailing are performed by fewer, much larger firms. These lead firms largely dictate the terms of chain membership, the incorporation or exclusion of actors, the functional division of labor, and the distribution of risks, costs and rewards. Increasingly, actors such as governments, large NGOs and certification bodies that do not directly handle the product also influence value chain governance. Agricultural producers, especially in developing countries, on the other hand, usually have little influence on the terms and outcomes of value chain arrangements. One implication of this governance structure is that upgrading smallholders in biofuel value chains will likely require identifying 'action points' - i.e. organizations, firms, regulatory frameworks and other sites where relationships and activities can be modified (Riisgaard et al., 2010). For example, feedstock farmers may benefit from linking up with fuel retailers or NGOs that can pressure processors to adopt certain sustainability standards. Such strategies are very resource demanding and so depend on external support as well as collective action among small producers.

Standards are used to govern an increasing share of global agricultural trade, and have been interpreted both as market access barriers and opportunities for low-income producers, exporters and workers (Gibbon et al., 2008; Henson, 2011; Humphrey, 2006). The biofuel initiatives reviewed here include criteria similar to those found in agro-food standards on food safety, sustainable production, and ethical trade; hence it is relevant to examine how conformity to these standards by smallholders has affected livelihoods. The literature suggests that welfare impacts from smallholder certification are limited, patchy and conditional (Henson, 2011; Humphrey, 2006). In this regard, Bolwig et al. (2013) identify several conditions that must be present for smallholder certification to improve livelihoods. These concern especially how the upstream segments of value chains are organized, including the capabilities and market linkages of the scheme operator, and hence shed more light on the 'production model' as a mediating factor of livelihood outcomes. Other conditions relate to product attributes, market characteristics, and infrastructure. While smallholder certification to standards can be straightforward, certification in forms that generate measurable and consistent benefits is highly demanding (Bolwig et al., 2013).

\subsubsection{Applicability and limitations of value chain insights}

Table 2 shows that many of the conditions for improving smallholder benefits identified by the agro-food literature also apply to biofuels. Still, these insights do not address the full set of livelihood and equity problems discussed in this paper. Despite Riisgaard et al.'s (2010) expanded definition of upgrading, many efforts to 'upgrade' smallholders have focused more on increasing income than on making gains related to gender, food security, social inclusion, or control over land and resources. Strategies such as relying on cooperatives or NGOs to engage with farmers about their options need to overcome barriers to equitable participation that currently tend to exclude, among others, indigenous people and those without secure land tenure. More fundamentally, inclusion in (global) value chains is not necessarily advantageous to smallscale producers (Hospes and Clancy, 2011). Hence it would be valuable to complement this analysis with a review of other strategies, including social movements for land reform and the expanded use of cooperatives to help farmers gain more power over the production and marketing processes.

\section{Conclusions}

Despite increased attention to sustainability in biofuel production, governance instruments remain relatively weak on livelihoods and equity, particularly when their level of implementation is taken into account. To change this, we suggest shifting the policy hierarchy in favor of multi-criteria goals that explicitly include attention to income, food, land access and their equity dimension - and re-prioritizing these policies so that if strong, mandatory goals cannot be met, then fuel blending or production mandates should not be pursued. Accomplishing this presents the challenge of ensuring that some criteria are not neglected in the pursuit of others. It is difficult to 'equally' address the livelihood dimensions discussed here, together with equity considerations across the value chain, for several reasons: some aspects are more measurable than others; some interventions are easier to implement than others; working across scales presents institutional challenges; and it is difficult to convince actors with strong stakes in the industry to agree to their own regulation. Given the diversity of pre-existing economic, social and political arrangements where biofuel crops are grown, it is not necessarily desirable to treat each of these considerations the same way in all times and places. Locally relevant criteria are therefore important.

The literature on governance and certification in non-energy agricultural value chains provides precedents for approaching some of these dilemmas. It suggests that producer upgrading can be one operational way to integrate livelihood concerns into biofuels deployment, e.g. by building the concept into certification schemes. Upgrading should involve not only adding new functions or increasing productivity, but also improving the terms under which producers and workers are incorporated into biofuels markets. Strategies that span multiple scales seem best suited to this task. To ensure positive welfare impacts for producers and workers, these actions should be accompanied by monitoring of key livelihood dimensions as discussed. Still, value chain approaches, including certification and standards, face the ongoing problem of how to encourage compliance.

This research suggests avenues for further investigation. One is to develop strategies for defining place-specific yet broadly relevant understandings of livelihoods and equity that could support the kind of inversion of the policy hierarchy we have proposed. Equity issues are fundamentally important to evaluating the sustainability of biofuel production but are particularly weakly specified in existing governance instruments. As well, it is crucial to move rural development assessment beyond income and job-related concerns toward a multi-dimensional understanding of rural poverty (Scheidel, 2013). A second line of inquiry concerns how to coordinate (and streamline) layers of relevant instruments, including improving enforcement of social and environmental protections not focused on biofuels. A third research question is how to make biofuel governance both more proactive and flexible. Measures that focus on anticipating and avoiding problems are more likely to protect livelihoods and equity than those focused on monitoring outcomes and ensuring redress, yet several of the instruments reviewed here include such reactive strategies (e.g. EU 
2009's reporting requirements, and the Voluntary Guidelines' recommendations to investors). Given the multi-scale, multi-sector and multi-institutional character of the problems involved and the rapid pace of change in this field, finding flexible approaches that build in adaptive capacity remains crucial.

\section{Acknowledgements}

CH was supported by a Postdoctoral Fellowship from the Social Sciences and Humanities Research Council (Canada). SB was supported by the Danish Council for Strategic Research and the Danish Ministry of Foreign Affairs. EC was supported by the Spanish Research, Development and Innovation Secretariat through a 'Ramón y Cajal' research fellowship (RYC-2010-07183) and by a Marie Curie Career Integration Grant within the 7th European Community Framework Programme (PCIG09-GA-2011-294234).

\section{References}

Ackrill, R., Kay, A., 2011. EU biofuels sustainability standards and certification systems - how to seek WTO-compatibility. Journal of Agricultural Economics 62 (3) , 551-564

Ariza-Montobbio, P., Lele, S., Kallis, G., Martinez-Alier, J., 2010. The political ecology of Jatropha plantations for biodiesel in Tamil Nadu, India. Journal of Peasant Studies 37 (4), 875-897.

Arndt, C., Msangi, S., Thurlow, J., 2011. Are biofuels good for African development? An analytical framework with evidence from Mozambique and Tanzania. Biofuels 2 (2), 221-234.

Bailis, R., Baka, J., 2011. Constructing sustainable biofuels: governance of the emerging biofuel economy. Annals of the Association of American Geographers 101 (4), 827-838.

Baka, J., 2013. The political construction of wasteland: governmentality, land acquisition and social inequality in South India. Development and Change 44 (2), 409-428.

Barrett, C.B., Bachke, M.E., Bellemare, M.F., Michelson, H.C., Narayanan, S., Walker T.F., 2012. Smallholder participation in contract farming: comparative evidence from five countries. World Development 40 (4), 715-730.

Bebbington, A., 1999. Capitals and capabilities: a framework for analyzing peasant viability, rural livelihoods and poverty. World Development 27 (12), 20212044.

Bhumiratana, A., Sorosjinda-Nunthawarasilp, P., Kaewwaen, W., Maneekan, P., Pimnon, S., 2013. Malaria-associated rubber plantations in Thailand. Travel Medicine and Infectious Disease 11 (1), 37-50.

Bolwig, S., Gibbon, P., Jones, S., 2009. The economics of smallholder organic contract farming in tropical Africa. World Development 37 (6), 1094-1104.

Bolwig, S., Ponte, S., Du Toit, A., Riisgaard, L., Halberg, N., 2010. Integrating poverty and environmental concerns into value-chain analysis: a conceptual framework. Development Policy Review 28 (2), 173-194.

Bolwig, S., Riisgaard, L., Gibbon, P., Ponte, S., 2013. Challenges of agro-food standards conformity: lessons from East Africa and policy implications. European Journal of Development Research. http://dx.doi.org/10.1057/ ejdr.2013.8 (advance online publication, 18.04.13)

Borras, S.M., Franco, J., 2012. Global land grabbing and trajectories of agrarian change: a preliminary analysis. Journal of Agrarian Change 12 (1), 34-59.

Borras Jr., S.M., Hall, R., Scoones, I., White, B., Wolford, W., 2011. Towards a better understanding of global land grabbing: an editorial introduction. Journal of Peasant Studies 38 (2), 209-216.

Browne, P., 2009. Tanzania Suspends Biofuel Investments. New York Times, New York.

César, A.d.S., Batalha, M.O., 2013. Brazilian biodiesel: the case of the palm's social projects. Energy Policy 56, 165-174.

Charnley, S., 2005. Industrial plantation forestry. Journal of Sustainable Forestry 21 (4), 35-57.

Cramb, R., Curry, G.N., 2012. Oil palm and rural livelihoods in the Asia-Pacific region: an overview. Asia Pacific Viewpoint 53 (3), 223-239.

Cramb, R.A., Sujang, P.S., 2013. The mouse deer and the crocodile: oil palm smallholders and livelihood strategies in Sarawak, Malaysia. Journal of Peasant Studies 40 (1), 129-154.

Creutzig, F., McGlynn, E., Minx, J., Edenhofer, O., 2011. Climate policies for road transport revisited (I): evaluation of the current framework. Energy Policy 39 (5), 2396-2406.

Creutzig, F., Popp, A., Plevin, R.J., Luderer, G., Minx, J., Edenhofer, O., 2012a. Reconciling top-down and bottom-up modeling on future bioenergy deployment. Nature Climate Change 2, 320-327.

Creutzig, F., von Stechow, C., Klein, D., Hunsberger, C., Bauer, N., Popp, A., Edenhofer, O., 2012b. Can bioenergy assessments deliver? Economics of Energy and Environmental Policy 1 (2), 65-82.

Creutzig, F., Corbera, E., Bolwig, S., Hunsberger, C., 2013. Integrating place-specific livelihood and equity outcomes into global assessments of bioenergy deployment. Environmental Research Letters 8, 035047.
Di Lucia, L., 2010. External governance and the EU policy for sustainable biofuels the case of Mozambique. Energy Policy 38 (11), 7395-7403.

Diaz Rios, L.B., Jaffee, S., Henson, S., Mugisha, J., 2009. Not yet up to standard. The legacy of two decades of private, governmental and donor efforts to promote Ugandan horticultural exports. The World Bank, Washington D.C.

Ellis, F., 2000. The determinants of rural livelihood diversification in developing countries. Journal of Agricultural Economics 51 (2), 289-302.

EU, 2003. Directive 2003/30/EC of the European Parliament and of the Council on the Promotion of Biofuels and Other Renewable Fuels for Transport, L 123/17. Official Journal of the European Union, Brussels.

EU, 2009. Directive 2009/28/EC of the European Parliament and of the Council on the Promotion of the Use of Energy from Renewable Sources, L 140/16. Official Journal of the European Union, Brussels.

Fairhead, J., Leach, M., Scoones, I., 2012. Green grabbing: a new appropriation of nature? Journal of Peasant Studies 39 (2), 237-261.

FAO, 2013. FAO Statistics. <http://faostat3.fao.org/home/>

Fargione, J., Hill, J., Tilman, D., Polasky, S., Hawthorne, P., 2008. Land clearing and the biofuel carbon debt. Science 319, 1235-1238.

Fargione, J.E., Plevin, R.J., Hill, J.D., 2010. The ecological impact of biofuels. Annual Review of Ecology, Evolution, and Systematics 41 (1), 351-377.

Fast, S., 2009. The biofuels debate: searching for the role of environmental justice in environmental discourse. Environments Journal 37 (1), 83-100.

Feintrenie, L., Chong, W.K., Levang, P., 2010. Why do farmers prefer oil palm? Lessons learnt from Bungo district, Indonesia. Small-Scale Forestry 9 (3), 379396.

Fox, J., 1993. The Politics of Food in Mexico: State Power and Social Mobilization. Cornell University Press, Ithaca.

Franco, J., Levidow, L., Fig, D., Goldfarb, L., Hönicke, M., Luisa Mendonça, M., 2010 Assumptions in the European Union biofuels policy: frictions with experiences in Germany, Brazil and Mozambique. Journal of Peasant Studies 37 (4), 661 698.

Gerber, J.-F., 2011. Conflicts over industrial tree plantations in the South: who, how and why? Global Environmental Change 21 (1), 165-176.

German, L., 2012. Multi-level governance of large-scale land acquisitions: mapping and evaluating the terrain. Land Deals Politics Initiative.

German, L., Schoneveld, G.C., 2012. A review of social sustainability considerations among EU-approved voluntary schemes for biofuels, with implications for rural livelihoods. Energy Policy.

German, L., Schoneveld, G.C., Pacheco, P., 2012. Special issue: local social and environmental impacts of biofuels. Ecology and Society 16.

Gibbon, P., Bair, J., Ponte, S., 2008. Governing global value chains: an introduction. Economy and Society 37 (3), 315-338.

Goldemberg, J., 2009. The Brazilian experience with biofuels. Innovations 4 (4), 91 107.

Gupta, A., 2012. Pesticide use in South and South-East Asia: environmental public health and legal concerns. American Journal of Environmental Sciences 8 (2) $152-157$.

Hall, D., 2003. The international political ecology of industrial shrimp aquaculture and industrial plantation forestry in Southeast Asia. Journal of Southeast Asian Studies 34 (2), 251-264.

Hall, D., 2011. Land grabs, land control, and Southeast Asian crop booms. Journal of Peasant Studies 38 (4), 837-857.

Hall, J., Matos, S., Severino, L., Beltrao, N., 2009. Brazilian biofuels and socia exclusion: established and concentrated ethanol versus emerging and dispersed biodiesel. Journal of Cleaner Production 17, S77-S85.

Henson, S., 2011. Private agrifood governance: conclusions, observations and provocations. Agriculture and Human Values 28 (3), 443-451.

Hertel, T.W., Golub, A., Jones, A.D., O'Hare, M., Plevin, R., Kammen, D.M., 2010. Global land use and greenhouse gas emissions impacts of U.S. maize ethanol: estimating market-mediated responses. Bioscience 60 (3), 223-231.

Hodbod, J., Tomei, J., 2013. Demystifying the social impacts of biofuels at local levels: where is the evidence? Geography Compass 7 (7), 478-488.

Hospes, O., Clancy, J., 2011. Unpacking the discourse on social inclusion in value chains. In: Helmsing, A.H.J., Vellema, S. (Eds.), Value Chains, Social Inclusion and Economic Development: Contrasting Theories and Realities. Routledge, Milton Park, UK, pp. 23-41.

Howarth, R.W., Bringezu, S., Bekunda, M., de Fraiture, C., Maene, L., Martinelli, L., Sala, O., 2009. Rapid assessment on biofuels and environment: overview and key findings. In: Bringezu, R.W.H.S. (Ed.), Biofuels: Environmental Consequences and Interactions with Changing Land Use. Proceedings of the Scientific Committee on Problems of the Environment (SCOPE) International Biofuels Project Rapid Assessment, 22-25 September, 2008, Gummersbach Germany. Cornell University, Ithaca, NY, USA, pp. 1-13.

Humphrey, J., Schmitz, H., 2002. How does insertion in global value chains affect upgrading in industrial clusters? Regional Studies 36 (9), 1017-1027.

Humphrey, J., 2006. Policy implications of trends in agribusiness value chains. The European Journal of Development Research 18 (4), 572-592.

Humphrey, J., Navas-Alemán, L., 2010. Value chains, donor interventions and poverty reduction: a review of donor practice. IDS Research Reports 2010 (63) $1-106$.

Hunsberger, C., 2013. Jatropha as a biofuel crop and the economy of appearances: experiences from Kenya. Review of African Political Economy.

IPCC, 2011. IPCC Special Report on Renewable Energy Sources and Climate Change Mitigation. In: Edenhofer, O., Pichs-Madruga, R., Sokona, Y., Seyboth, K. Matschoss, P., Kadner, S., Zwickel, T., Eickemeier, P., Hansen, G., Schlömer, S. Von Stechow, C. (Eds.), Prepared by Working Group III of the Intergovernmental 
Panel on Climate Change. Cambridge University Press, Cambridge, United Kingdom and New York, NY, USA.

ISCC, 2011. Sustainability Requirements for the Production of Biomass International Sustainability and Carbon Certification, Cologne.

ISCC, 2013a. Membership List. <http://www.iscc-system.org/en/iscc-association/ membership-list>.

ISCC, 2013b. Valid Certificates. <http://www.iscc-system.org/en/certificate-holders valid-certificates>.

Jaffee, S., Henson, S., Diaz Rios, L., 2011. Making the Grade: Smallholder Farmers, Emerging Standards, and Development Assistance Programs in Africa. The World Bank, Washington, DC.

Jones, S., Gibbon, P., 2011. Developing agricultural markets in sub-Saharan Africa: organic cocoa in rural Uganda. Journal of Development Studies 47 (10), 1595 1618.

Julia, White, B., 2012. Gendered experiences of dispossession: oil palm expansion in a Dayak Hibun community in West Kalimantan. Journal of Peasant Studies 39 (3-4), 995-1016.

Kenney-Lazar, M., 2012. Plantation rubber, land grabbing and social-property transformation in southern Laos. Journal of Peasant Studies 39 (3-4), 1017 1037.

Kuchler, M., Linnér, B.O., 2012. Challenging the food vs. fuel dilemma: genealogical analysis of the biofuel discourse pursued by international organizations. Food Policy 37 (5), 581-588.

Laurance, W.F., Koh, L.P., Butler, R., Sodhi, N.S., Bradshaw, C.J.A., Neidel, J.D., Consunji, H., Mateo Vega, J., 2010. Improving the performance of the roundtable on sustainable palm oil for nature conservation. Conservation Biology 24 (2), $377-381$.

Lee, J.S.H., Rist, L., Obidzinski, K., Ghazoul, J., Koh, L.P., 2011. No farmer left behind in sustainable biofuel production. Biological Conservation 144 (10), 2512-2516.

Li, T.M., 2002. Local histories, global markets: cocoa and class in upland Sulawesi. Development and Change 33 (3), 415-443.

McCarthy, J.F., 2010. Processes of inclusion and adverse incorporation: oil palm and agrarian change in Sumatra, Indonesia. Journal of Peasant Studies 37 (4), 821 850.

McMichael, P., Scoones, I., 2010. Special issue: the politics of biofuels, land and agrarian change. Journal of Peasant Studies 37

Mingorría, S., Gamboa, G., 2010. Metabolismo socio-ecológico de comunidades campesinas Q'eqchi' y la expansión de la agro-industria de caña de azúcar y palma africana: Valle del Río Polochic, Guatemala. Instituto de Ciencia Tecnología Ambiental, Universidad Autónoma de Barcelona (ICTA/UAB) y el Instituto de Estudios Agrarios de la Coordinación de ONGs y Cooperativas (IDEAR/CONGCOOP). Magnaterra Editores.

Mink, P.J., Mandel, J.S., Sceurman, B.K., Lundin, J.I., 2012. Epidemiologic studies of glyphosate and cancer: a review. Regulatory Toxicology and Pharmacology: RTP 63 (3), 440-452.

Mitchell, D., 2008. A Note on Rising Food Prices. World Bank Policy Research Working Paper Series.

Mitchell, J., Coles, C., 2011. Markets and Rural Poverty: Upgrading in Value Chains. IDRC, Ottawa.

Obidzinski, K., Andriani, R., Komarudin, H., Andrianto, A., 2012. Environmental and social impacts of oil palm plantations and their implications for biofuel production in Indonesia. Ecology and Society 17 (1).

Parfit, D., 1997. Equality and priority. Ratio 10, 202-221.

Partzsch, L., 2011. The legitimacy of biofuel certification. Agriculture and Human Values 28 (3), 413-425.

Petschel-Held, G., Schellnhuber, H.J., Bruckner, T., Toth, F.L., Hasselmann, K., 1999 The tolerable windows approach: theoretical and methodological foundations. Climatic Change 41 (3-4), 303-331.

Pinstrup-Andersen, P., 2009. Food security: definition and measurement. Food Security 1 (1), 5-7.

Renewable Fuels Agency, 2010. Benchmarks of Sustainability Standards and Certification Schemes. <http://webarchive.nationalarchives.gov.uk/20110 407094507/, http://renewablefuelsagency.gov.uk/>.
Ribot, J.C., Peluso, N.L., 2003. A theory of access. Rural Sociology 68 (2), $153-181$.

Riisgaard, L., Bolwig, S., Ponte, S., Du Toit, A., Halberg, N., Matose, F., 2010. Integrating poverty and environmental concerns into value-chain analysis: a strategic framework and practical guide. Development Policy Review 28 (2), $195-216$.

Rist, L., Feintrenie, L., Levang, P., 2010. The livelihood impacts of oil palm: smallholders in Indonesia. Biodiversity and Conservation 19 (4), 1009-1024.

RSB, 2010. RSB Principles and Criteria for Sustainable Biofuel Production, Version 2.0. Roundtable on Sustainable Biofuels, Lausanne.

RSB, 2011. Annual Report 2011. Roundtable on Sustainable Biofuels, Lausanne.

RSB, 2013a. RSB Certificates. <http://rsbservices.org/certificates>.

RSB, 2013b. RSB Members. <http://rsb.org/about/organization/rsb-members>.

RSPO, 2012. ACOP Digest: A Snapshot of RSPO Members' Annual Communications of Progress. Roundtable on Sustainable Palm Oil, Kuala Lumpur.

RTRS, 2013. Certified Producers. <http://www.responsiblesoy.org/index.php? option=com_content\&view=article\&id=297\&Itemid=181\&lang=en>.

Sauer, S., Leite, S.P., 2012. Agrarian structure, foreign investment in land, and land prices in Brazil. Journal of Peasant Studies 39 (3-4), 873-898.

Scheidel, A., 2013. Flows, funds and the complexity of deprivation: using concepts from ecological economics for the study of poverty. Ecological Economics 86, $28-36$.

Schoneveld, G.C., German, L.A., Nutakor, E., 2011. Land-based investments for rural development? A grounded analysis of the local impacts of biofuel feedstock plantations in Ghana. Ecology and Society 16 (4).

Schouten, G., Leroy, P., Glasbergen, P., 2012. On the deliberative capacity of private multi-stakeholder governance: the roundtables on responsible soy and sustainable palm oil. Ecological Economics 83, 42-50.

Schut, M., Leeuwis, C., van Paassen, A., 2013. Ex ante scale dynamics analysis in the policy debate on sustainable biofuels in Mozambique. Ecology and Society $18(1)$, article 20

Scoones, I., 1998. Sustainable Rural Livelihoods: A Framework for Analysis. Institute of Development Studies, Brighton.

Scoones, I., 2009. Livelihoods perspectives and rural development. Journal of Peasant Studies 36 (1), 171-196.

Searchinger, T., Heimlich, R., Houghton, R.A., Dong, F., Elobeid, A., Fabiosa, J., Tokgoz, S., Hayes, D., Yu, T.-H., 2008. Use of U.S. croplands for biofuels increases greenhouse gases through emissions from land-use change. Science 319, 12381240 .

Sikor, T., Auld, G, Bebbington, A.J., Benjaminsen, T.A., Gentry, B.S., Hunsberger, C. Izac, A.-M., Margulis, M.E., Plieninger, T., Schroeder, H., Upton, C., 2013. Global land governance: from territory to flow? Current Opinion in Environmental Sustainability 5 (5), 522-527.

Skutsch, M., de los Rios, E., Solis, S., Riegelhaupt, E., Hinojosa, D., Gerfert, S., Gao, Y., Masera, O., 2011. Jatropha in Mexico: environmental and social impacts of an incipient biofuel program. Ecology and Society 16(4).

Tanga, M.C., Ngundu, W.I. Tchouassi, P.D. 2011. Daily survival and human blood index of major malaria vectors associated with oil palm cultivation in Cameroon and their role in malaria transmission. Tropical Medicine \& International Health 16 (4), 447-457.

Temkin, L.S., 2003. Equality, priority or what? Economics and Philosophy 19, 6187.

USDA Foreign Agricultural Service, 2011. Indonesia Forest Moratorium 2011. Global Agricultural Information Network, Jakarta.

Wilkinson, J., Herrera, S., 2010. Biofuels in Brazil: debates and impacts. Journal of Peasant Studies 37 (4), 749-768.

Williams, A.L., Watson, R.E., DeSesso, J.M., 2012. Developmental and reproductive outcomes in humans and animals after glyphosate exposure: a critical analysis. Journal of Toxicology and Environmental Health. Part B, Critical Reviews 15 (1), 39-96.

Woodhouse, P. 2012. Foreign agricultural land acquisition and the visibility of water resource impacts in Sub-Saharan Africa. Water Alternatives 5 (2), 208 222. 